\title{
Pengembangan Perangkat Pembelajaran Persamaan dan Pertidaksamaan Nilai Mutlak Linear Satu Variabel Bagi Siswa yang Mengalami Hambatan Belajar Matematika
}

\author{
Lisaiha Rodiyya Basori ${ }^{1}$, Jailani ${ }^{2}$ \\ ${ }^{1}$ SMAN 1 Turi \\ ${ }^{2}$ Universitas Negeri Yogyakarta. \\ E-mail: miaysmp6@gmail.com ${ }^{1}$; jailani@uny.ac.id²
}

\begin{abstract}
Abstrak
Penelitian ini bertujuan untuk: (1) menghasilkan perangkat pembelajaran matematika kelas $\mathrm{X}$ bagi siswa yang mengalami hambatan belajar dalam pembelajaran matematika, dan (2) mendefinisikan kualitas perangkat pembelajaran yang dikembangkan berdasarkan aspek: kevalidan, kepraktisan, dan keefektifan. Penelitian pengembangan ini menggunakan model pengembangan 4-D yang dikembangkan oleh S. Thiagarajan, Semmel, D.S. dan Semmel, M.I. Penelitian ini menghasilkan perangkat pembelajaran matematika kelas X bagi siswa yang mengalami hambatan belajar dalam pembelajaran matematika. Perangkat pembelajaran yang dikembangkan valid, yang ditunjukkan oleh klasifikasi secara kualitatif adalah "sangat baik" untuk dosen ahli 1 serta "cukup" untuk dosen ahli 2; praktis, yang ditunjukkan oleh hasil penilaian kepraktisan oleh guru berada pada kategori "sangat baik" untuk RPP dan "baik" untuk LKS, hasil penilaian kepraktisan oleh siswa yaitu berada pada kategori "baik", dan rata-rata persentase keterlaksanaan pembelajaran kegiatan guru dan siswa di atas 90\%; dan efektif ditinjau dari hasil tes akhir siswa dengan persentase ketuntasan belajar mencapai 70,58\%.
\end{abstract}

Kata kunci: Perangkat pembelajaran; Belajar; Hambatan belajar

\section{Developing Mathematics Learning Kit Of Linear Equations And Inequalities Absolute Value One Variables For The Students Those Having Face Problems In Mathematics}

\begin{abstract}
This study aims to: (1) develop a mathematics learning kit for the first semester of grade $\mathrm{X}$ students those having face problems in mathematics, and (2) define the quality of the developed learning kit based on the aspects of: validity, practicality, and effectiveness. This research and development employed the 4-D development model proposed by S. Thiagarajan, Semmel, D.S. and Semmel, M.I. The result of this study is in the form a mathematics learning kit of SMA indicated to have face problems in mathematics. The learning kit that has been developed is considered valid which can be categorized as "very good" from the first expert lecturer and "plenty" from the second expert lecturer; practical based on the result of the practicality questionnaire result from the teachers which can be categorized as "very good", while the result of practicality questionnaire from the students can be categorized as "good" with the average percentage of the teacher and students' implementation for the learning activity being more than 90\%; and effective as can be seen from the students' learning mastery percentage of 70,58\%.
\end{abstract}

Keywords: Learning kit; Learning; Face problems in learning 


\section{PENDAHULUAN}

Pendidikan merupakan instrumen canggih dalam suatu perubahan sosial, karena seringkali menginisiasi pergeseran pada sebuah struktur sosial. Dengan demikian, pendidikan membantu menjembatani kesenjangan antar kelompok masyarakat yang berbeda (NCERT, 2006, p.1). Dalam kegiatan pembelajaran, guru dituntut untuk mampu menggunakan perangkat pembelajaran yang relevan dengan kebutuhan siswa dan materi pembelajran yang dibahas untuk mencapai tujuan pembelajaran yang ditetapkan (Sadidah \& Wijaya, 2006, p.6.). Namun tidak semua guru dapat mengakomodir kebutuhan siswa dengan baik, mereka membutuhkan bantuan perangkat pembelajaran yang sesuai bagi siswa-siswa tertentu yang masih membutuhkan bimbingan khusus dari guru.

Matematika sebagai salah satu cabang ilmu pengetahuan yang wajib dipelajari oleh seorang siswa sejak menginjakkan kaki di sekolah dasar sampai perguruan tinggi tentunya menjadi mata pelajaran yang tidak bisa dihindari, namun keberadaannya masih dipandang menyeramkan oleh sebagian siswa. Baik dikarenakan pembelajaran yang membosankan maupun pengajaran yang disampaikan guru nampak seperti kehabisan ide, terlihat dari kurangnya inovasi yang dikhususkan untuk membangkitkan semangat belajar matematika bagi para siswa.

Kesulitan belajar matematika merupakan suatu rintangan, halangan, maupun kesukaran matematika yang meliputi banyak hal dan harus dihadapi siswa (Rumasoreng \& Sugiman, 2014, p.24). Dengan dukungan guru dan perangkat pembelajaran yang memadai, niscaya kesulitan yang dihadapi siswa dapat segera teratasi dan tujuan pembelajaran yang diinginkan dapat tercapai secara optimal. Belajar adalah proses alami pertumbuhan menuju kedewasaan diri seseorang yang secara alamiah telah dikaruniai kemampuan potensial tersebut. Namun di sisi lain, belajar adalah semacam perubahan yang bersifat kekal dan berperan penting dalam kehidupan pembelajar (Fink, 2003, p.6).

Belajar adalah sebuah proses rekonstruksi aktif terhadap skema yang ada (Benassi, Overson, \& Hakala [Ed.], 2014, p.1). Selama belajar, skema yang relevan disimpan dalam memori jangka panjang yang dapat diaktifkan kembali serta terintegrasi dengan informasi yang masuk dalam memori siswa sehingga dapat membangun pengetahuan dengan lebih maju serta keterampilan siswa. Apabila belajar didasarkan pada konteks, melakukan generalisasi di dalam pembelajaran untuk konteks baru tidak dapat dilakukan secara spontan melainkan perlu adanya fasilitasi. Seringkali, bukti transfer positif tidak muncul sampai siswa memiliki kesempatan untuk belajar tentang domain baru dan kemudian kegiatan transfer belajar terjadi sehingga tampak jelas bahwa dalam kemampuan siswa/pembelajar untuk memahami informasi baru lebih cepat dari sebelumnya (Bransford, Brown, \& Cocking [Ed.], 1999, p.10).

Belajar secara umum didefinisikan sebagai perubahan yang relatif permanen dalam perilaku, keterampilan, pengetahuan, atau sikap yang teridentifikasi dihasilkan dari pengalaman psikologis atau sosial. Fitur utama adalah keabadian: perubahan tidak dihitung sebagai pembelajaran jika hal tersebut bersifat sementara. Perubahan harus bertahan lama, baik itu pembelajaran yang didapat oleh aspek fisik, sosial, atau emosional serta kognitif siswa (Seifert \& Sutton, 2009, p.20). Perubahan yang relatif permanen dalam perilaku siswa yang dibuktikan dengan perubahan dalam kinerja sebagai hasil yang diperkuat dengan latihan, pelatihan atau pengalaman.

Ada faktor-faktor tertentu yang jelas mempengaruhi kegiatan belajar dan sebaiknya disadari sehingga guru dapat mengetahui bagaimana untuk membimbing siswa dalam kegiatan pembelajaran yang efektif antara lain: siswa, materi yang harus dipelajari, dan metode/teknik pembelajaran, sehingga hambatan-hambatan yang mempengaruhi belajar tertuju pada ketiga faktor yang mempengaruhi belajar tersebut. Jika seorang guru memiliki siswa yang memiliki hambatan belajar atau masalah sikap yang parah, siswasiswa tersebut diarahkan untuk tes individu. Kemudian siswa yang teridentifikasi sebagai siswa berkebutuhan khusus tersebut masih diperlukan untuk diuji, namun nilai hasil pengujian tersebut tidak berpengaruh terhadap skor sekolah keseluruhan (Brantingler, 2006, p.17). Hambatan yang mungkin dialami siswa dalam belajar berkaitan dengan faktor-faktor berikut ini: kecerdasan siswa, sikap siswa, minat siswa, motivasi siswa, faktor lingkungan sosial siswa, faktor lingkungan non sosial siswa, materi yang harus dipelajari siswa, dan 
metode/teknik pembelajaran yang diterapkan kepada siswa saat kegiatan pembelajaran berlangsung.

Fasilitas sekolah yang ideal serta konseling tepat waktu akan mencegah siswa yang mengalami hambatan belajar tersebut tinggal kelas dan menjadi putus sekolah (Arjmandnia \& Kakabaraee, 2011, p.88). Siswa yang mengalami hambatan belajar bukanlah ketidakmampuan belajar atau kategori diagnostik. Ini berarti bahwa siswa tersebut menderita rendahnya tingkat pemahaman untuk materi pembelajaran. Oleh karena itu, mereka perlu strategi pendidikan yang disesuaikan. Siswa yang mengalami hambatan dalam memperoleh keterampilan ilmu hitung kemungkinan mengalami hambatan memahami konsep bilangan sederhana dan kurang memiliki pemahaman intuitif angka, yang mempengaruhinya juga dalam pembelajaran matematika namun tidak untuk mata pelajaran lain. Siswa tersebut mungkin unggul dalam mata pelajaran non-matematika.

Masalah-masalah yang teridentifikasi dalam penelitian ini antara lain: matematika masih menjadi mata pelajaran yang dihindari oleh sebagian siswa; masih ditemui kesalahan siswa dalam memahami konsep awal matematika; hambatan siswa dalam matematika belum diakomodasi secara khusus. Matematika adalah ilmu operasi terampil dengan konsep dan aturan yang diciptakan hanya untuk suatu tujuan tertentu. Penekanan utama adalah pada penemuan konsep (Wigner, 1960, p.1). Konsep standar matematika antara lain kepastian, keobyektifan, bukti penting, diagram, diagram yang menyesatkan, logika klasik, sense experience, akumulasi sejarah, pembuktian menggunakan komputer, serta menyelesaikan masalah (Brown, 1999, p.6).

Konsep dalam matematika adalah suatu ide abstrak yang memungkinkan seseorang untuk dapat mengklasifikasikan suatu objek atau kejadian serta menerangkan apakah objek atau kejadian tersebut merupakan contoh atau bukan contoh dari ide tersebut, yang di dalam matematika merupakan suatu yang abstrak, maka tak heran apabila guru mengalami kesulitan dalam menanamkan konsep matematika itu sendiri (Hasratuddin, 2008, pp.68-69), padahal penanaman konsep yang baik sangat dibutuhkan oleh siswa untuk dapat memahami pembelajaran dengan baik. Konsep standar matematika antara lain kepastian, keobyektifan, bukti penting, diagram, diagram yang menyesatkan, logika klasik, sense experience, akumulasi sejarah, pembuktian menggunakan komputer, serta menyelesaikan masalah (Brown, 1999, p.6). Secara intern, bagian penting dari matematika adalah konstruksinya dan sisi perhitungannya. Hal ini sangat bergantung kepada penyajian proses matematika secara dinamis seperti rekursi, iterasi, bukti suatu teorema, dan sebagainya (Marsigit, Rizkianto, Murdiyani, 2014, p.74).

Berdasarkan permendikbud nomor 24 tahun 2016 tentang kompetensi inti dan kompetensi dasar pelajaran pada kurikulum 2013 pada pendidikan dasar dan pendidikan menengah memaparkan kompetensi dasar yang terdapat dalam matematika SMA dan digunakan sebagai materi yang dikembangkan dalam perangkat pembelajaran pada penelitian ini adalah: mengintepretasi persamaan dan pertidaksamaan nilai mutlak dari bentuk linear satu variabel dengan persamaan dan pertidaksamaan linear Aljabar lainnya.

Siswa yang memiliki hambatan belajar dalam pembelajaran matematika memerlukan bimbingan yang lebih intensif dari guru yang bersangkutan. Guru dituntut untuk dapat memberikan arahan bagi siswa dalam mengerjakan latihan-latihan soal, dan guru pula yang menentukan rekan kerja siswa dalam mengerjakan latihan tersebut. Hal ini dilakukan demi menghindari kesenjangan siswa yang hanya berinteraksi dengan orang-orang tertentu saja.

Dalam setiap pertemuan, guru dapat merancang kelompok belajar bagi siswa-siswa yang membutuhkan tambahan pelajaran di rumah yang anggota dalam tiap-tiap kelompok dipilih secara acak agar semua siswa merasakan berkelompok, bekerja sama, maupun berinteraksi dengan berbagai macam jenis teman yang ada di kelasnya. Karena dalam satu kelas biasanya terdapat siswa yang pandai, ada pula siswa yang kurang pandai, ada siswa yang rajin, ada pula siswa yang kurang rajin, ada siswa yang pemarah dan kurang sabaran, ada pula siswa yang ramah dan sangat sabar. Guru tentu lebih mengetahui karakteristik berbagai macam siswa tersebut. Terkadang ada beberapa siswa yang tidak mau dijadikan sekelompok dengan siswa tertentu dan itu menjadi tantangan tersendiri bagi guru untuk pengelolaan kelompok belajar bagi siswa. 
Pada tiap akhir kegiatan pembelajaran guru melakukan evaluasi formatif, setelah adanya evaluasi formatif tersebut anak-anak yang belum menguasai bahan pelajaran diberikan pengajaran remedial, guru yang harus memberikan pelayanan pengajaran remedial disebut guru remedial (Remedial Teacher) yang khusus memberikan pelayanan pengajaran bagi anak-anak yang mengalami hambatan belajar (Abdurrahman, 2003, p.18).

Solusi yang ditawarkan untuk siswa yang mengalami hambatan belajar antara lain (Abdurrahman, 2003, p. 19), anak-anak yang mengalami hambatan belajar dalam matematika memerlukan lebih banyak pengalaman dengan belajar prabilangan sebagai landasan belajar matematika. Perlu adanya proses analisis tugas, menetapkan tujuan khusus, dan merancang urutan pembelajaran ditambah dengan alokasi waktu yang cukup untuk mempelajari tiap langkah urutan dalam setiap kegiatan pembelajaran matematika. Selain itu guru perlu mendorong siswa untuk bertanya kepada diri sendiri tentang berbagai pertanyaan agar secara kognitif mereka memproses informasi sebagai strategi pemecahan masalah, dan mengembangkan pendekatan mereka sendiri dalam belajar dan berpikir tentang matematika. Setelah kegiatan pembelajaran selesai, perlu dilakukan bimbingan dan latihan yang cukup serta belajar mengkombinasikan berpikir dan berbahasa dengan keterampilan menghitung dan konsep-konsep yang diperlukan dalam pemecahan masalah matematika.

Sebagai persiapan dalam kegiatan pembelajaran, guru perlu menyediakan berbagai informasi tentang apa yang diperlukan untuk kegiatan pembelajaran yang rinciannya dapat didefinisikan dari tujuan dan hasil belajar. Manfaat utama dari mendefinisikan tujuan dan hasil belajar adalah guru dapat menyediakan pedoman dari apa saja yang ingin dicapai dalam kegiatan pembelajaran tersebut. Hasil persiapan yang dilakukan oleh guru tertuang dalam bentuk perangkat pembelajaran yang digunakan sebagai pedoman untuk mencapai tujuan dan hasil belajar siswa sesuai dengan standar yang dituntut dari mereka (Butcher, Davies \& Highton, 2006, 25). Dengan kata lain dapat diartikan bahwa perangkat pembelajaran merupakan hasil nyata persiapan yang dilakukan oleh guru berisi berbagai informasi yang diperlukan untuk kegiatan pembelajaran yang digunakan sebagai pedoman dalam pembelajaran untuk mencapai tujuan dan hasil belajar sesuai dengan kompetensi yang diinginkan.

Beberapa penelitian yang relevan dengan penelitian ini antara lain:

Dalam penelitian berjudul Strategies and Interventions to Support Students with Mathematics Disabilities, disimpulkan bahwa Mengembangkan keterampilan matematika dasar dari tingkat dasar sangat penting. Mempertahankan keterampilan dasar yang diperoleh selama beberapa tahun di sekolah sangat penting sebagai pijakan siswa untuk bergerak menuju ke arah komputasi yang lebih maju, nilai tempat, dan konsep pecahan. Bagi siswa berpindah dari matematika dasar hingga matematika sekunder, adalah penting bahwa siswa mempertahankan dan menguasai keterampilan matematika tersebut dan guru terus memberikan instruksi yang berkesinambungan serta memberikan dukungan untuk memastikan bahwa keterampilan dasar dapat tertangani dengan sempurna oleh siswa sebelum siswa mengakses konsep matematika yang lebih lanjut (Hott, Isabell, \& Montani, 2014, p.1).

Kesimpulan dalam penelitian berjudul The Assessment of Math Learning Difficulties in a Primary Grade-4 Child with High Support Needs: Mixed Methods Approach dikatakan bahwa hambatan terbesar yang dialami siswa dalam pembelajaran matematika antara lain ketidakmampuan untuk menggunakan empat operasi aritmatika (penjumlahan, pengurangan, perkalian, pembagian), atau lebih spesifiknya tidak memahami hubungan antara unit, misalnya dalam unit puluhan dengan unit ratusan; hambatan dalam menggunakan dua dari empat proses aritmatika $(+,-, \mathrm{x}, \div)$ pada kombinasi dalam satu operasi; memperlakukan setiap kolom (dalam suatu operasi) sebagai masalah yang terpisah; masalah nilai tempat/keselarasan yang salah dari penjumlahan; koordinasi mata-tangan yang buruk menyebabkan disgrafia; dan penyimpangan memori. Masalah lain yang menjadi jelas melalui penyelidikan ini dan tersirat dalam temuan termasuk faktor-faktor penyebab yang mungkin seperti dyscalculia, disleksia, rendah diri, tingkat efikasi diri rendah, dan kecemasan dalam matematika (Mundia, 2012, p.1).

Penelitian yang dilakukan oleh Tarzimah Tambychik dan Thamby Subahan Mohd 
Meerah berjudul, Students' Difficulties in Mathematics Problem-Solving: What do they Say? Yang meneliti tentang hambatan yang dialami siswa dalam menentukan penyelesaian masalah dalam matematika. Temuan data menunjukkan bahwa siswa mengalami hambatan dalam beberapa keterampilan matematika seperti perhitungan, keterampilan visual-spasial dan informasi. Hambatan dalam keterampilan matematika serta kemampuan kognitif dalam pembelajaran menghambat penyelesaian masalah matematika. Pemahaman yang diperoleh dari hasil penelitian tersebut adalah tentang bagaimana hambatan dalam beberapa keterampilan matematika tersebut mempengaruhi penyelesaian masalah ini diharapkan dapat memberikan garis panduan yang efektif dalam mempersiapkan instrumen dan modul belajar untuk mengembangkan keterampilan matematika. (Tambychik \& Meerah, 2010, pp.37-38)

Penelitian ini bertujuan untuk: menghasilkan perangkat pembelajaran matematika kelas X bagi siswa yang mengalami hambatan belajar dalam matematika; mengetahui kualitas perangkat pembelajaran matematika kelas $\mathrm{X}$ bagi siswa yang mengalami hambatan belajar dalam matematika berdasarkan aspek: kevalidan, kepraktisan, dan keefektifan.

\section{METODE PENELITIAN}

\section{Jenis Penelitian}

Penelitian ini merupakan penelitian pengembangan. Pengembangan perangkat pembelajaran menggunakan desain 3-D yang diadaptasi dari model 4-D antara lain Define (pendefinisian), Design (perancangan) dan Development (pengembangan)

\section{Waktu dan Tempat Penelitian}

Penelitian dilaksanakan di kelas X MIPA 1 SMA N 1 Turi pada semester ganjil tahun ajaran 2016/2017 pada tanggal 29 Juli 2016 sampai 3 September 2016.

\section{Target/Subjek Penelitian}

Subjek coba dalam penelitian ini adalah siswa kelas X MIPA 1. Setelah melakukan assesmen pra pembelajaran diperoleh 17 siswa dari total 32 siswa di kelas X MIPA 1 yang terindikasi mengalami hambatan belajar matematika.

\section{Prosedur}

Prosedur pengembangan perangkat pembelajaran bagi siswa yang mengalami hambatan belajar dalam pembelajaran matematika mengacu pada fase-fase desain penelitian yang dirumuskan dalam Pengembangan perangkat pembelajaran menggunakan desain yang dikemukakan oleh $\mathrm{S}$. Thiagarajan menggunakan tahap-tahap sebagai berikut (Thiagarajan, Semmel, Semmel, 1974, p. 5-9): define (pendefinisian), design (perancangan), dan development (pengembangan).

\section{Data, Intrumen, dan Teknik Pengumpulan Data}

Data yang telah dikumpulkan dibagi menjadi dua bagian yaitu : 1) data dari evaluasi pertama, berupa data hasil review ahli/validator, berupa data kuantitatif dari lembar validasi dan kualitatif dari saran dan masukan yang diberikan, 2) data dari hasil penilaian oleh guru dan siswa berupa data kuantitatif dari hasil angket dan data kualitatif dari saran dan masukan yang diberikan. Kedua bagian data tersebut diperoleh dari hasil review berupa tanggapan langsung pada angket dari ahli/validator, guru pengampu mata pelajaran dan siswa.

\section{Teknik Analisis Data}

Teknik analisis data dilakukan untuk mendapatkan produk perangkat pembelajaran bagi siswa yang mengalami hambatan belajar dalam pembelajaran matematika yang berkualitas dan memenuhi aspek kevalidan, kepraktisan, dan keefektifan. Teknik analisis data dalam penelitian ini terdiri dari:

\section{Analisis Kevalidan}

Teknik yang digunakan untuk menganalisis data hasil validasi perangkat pembelajaran adalah persepsi validator. Jenis data yang diperoleh adalah data kuantitatif dan data kualitatif. Data kuantitatif berupa nilai persentase persepsi validator yang diperoleh dari lembar validasi, sedangkan data kualitatif berupa saran, kritik, dan tanggapan dari validator. Teknik analisis data kevalidan bertujuan untuk mengetahui apakah perangkat pembelajaran yang dibuat telah memenuhi kriteria kevalidan berdasarkan penilaian para ahli. 
Analisis Kepraktisan

\section{Analisis Data Penilaian Guru}

Kepraktisan perangkat pembelajaran yang dikembangkan salah satunya berdasarkan hasil penilaian guru yang menggunakan perangkat pembelajaran dalam pembelajaran. Perangkat pembelajaran matematika bagi siswa yang mengalami hambatan belajar dalam pembelajaran matematika yang dikembangkan dikatakan praktis jika penilaian guru minimal dalam kategori "membantu". Data tentang respon guru diperoleh dari angket respon guru terhadap perangkat pembelajaran yang dianalisis dengan rumus persepsi responden. Jenis data yang diperoleh adalah data kuantitatif dan data kualitatif. Data kuantitatif berupa nilai persepsi responden yang diperoleh dari angket respon guru terhadap perangkat pembelajaran, sedangkan data kualitatif berupa pendapat dari responden.

1) Analisis Data Penilaian Siswa

Data tentang penilaian siswa diperoleh dari angket respon siswa terhadap perangkat pembelajaran.

2) Analisis Data Lembar Observasi Keterlaksanaan Pembelajaran

Analisis dilakukan dengan menghitung persentase keterlaksanaan kegiatan pembelajaran matematika pada setiap pertemuan.

\section{Analisis Keefektifan}

Keefektifan perangkat pembelajaran dilihat dari ketuntasan belajar berdasarkan tes akhir. Skor yang diperoleh dari tes akhir dikonversi menjadi nilai dengan rentang 0 sampai dengan 100.

\section{HASIL DAN PEMBAHASAN}

Proses pengembangan perangkat pembelajaran kelas $\mathrm{X}$ semester ganjil bagi siswa yang mengalami hambatan belajar dalam pembelajaran matematika, materi persamaan dan pertidaksamaan nilai mutlak linear satu variabel terdiri dari beberapa tahapan sesuai dengan model pengembangan Thiagarajan yang meliputi:

\section{Define}

Pada tahap ini dilakukan kegiatan analisis ujung depan, analisis siswa, analisis konsep, analisis tugas serta analisis spesifikasi tujuan pembelajaran.
Pada kegiatan analisis ujung depan peneliti melakukan diskusi dengan guru matematika di kelas X MIPA 1 SMA N 1 Turi, yaitu ibu Retno Kuntari. Dari diskusi yang didapatkan beberapa informasi mengenai permasalahan yang dihadapi dalam kegiatan pembelajaran matematika antara lain, susunan materi untuk kurikulum terbaru berbeda dengan tahun lalu sehingga guru harus membuat bahan ajar serta kelengkapan perangkat lainnya untuk digunakan setahun kedepan. Buku-buku serta LKS yang dipakai tahun lalu juga sudah tidak relevan lagi untuk digunakan sebagai bahan pembelajaran. Jangankan untuk anak yang mengalami hambatan belajar, perangkat pembelajaran untuk anak yang tidak mengalami hambatan belajar saja belum selesai disusun, padahal ada beberapa siswa di kelas X MIPA 1 yang dicurigai oleh guru mengalami hambatan belajar namun belum dicarikan solusi untuk mengatasinya. Selain berdiskusi dengan guru, peneliti juga melakukan observasi di kelas $X$ MIPA 1. Dari observasi dan wawancara singkat dengan siswa yang dilakukan secara acak, peneliti menyimpulkan bahwa siswa sering mengalami hambatan pemahaman terhadap maksud yang disampaikan dalam pembelajaran, misalnya dalam LKS. Siswa mengharapkan penjelasan dalam LKS sedetail mungkin sehingga memudahkan dalam pengerjaannya.

Penanganan terhadap siswa yang mengalami hambatan belajar, akan dibantu dengan pengadaan tambahan pembelajaran atau dalam hal ini adalah pembelajaran remedial. Pembelajaran remedial menekankan bimbingan individual pada siswa sehingga bisa ditangani dengan seksama hal-hal yang mengakibatkan siswa tersebut mengalami hambatan belajar. Sebagai bahan acuan dan kelengkapan pembelajaran tersebut maka disusunlah perangkat pembelajaran, dalam hal ini RPP dan LKS.

Setelah dilakukan kegiatan analisis siswa, diperoleh data siswa yang menjadi subjek dalam penelitian ini adalah siswa SMA kelas X yang memiliki usia kisaran 15-16 tahun. Karakteristik dalam pembelajaran matematika beraneka ragam, ada siswa yang mengalami hambatan dalam menentukan himpunan penyelesaian suatu persamaan atau mencari nilai $x$ yang sesuai dalam suatu persamaan, terdapat siswa yang kurang teliti dalam menghitung/menentukan suatu bilangan apakah bilangan tersebut bernilai positif atau negatif, 
terdapat siswa yang mengalami ketidaktelitian dalam penentuan nilai $x$ dalam pertidaksamaan yang melibatkan pembagian dengan bilangan negatif, kesulitan membedakan bilangan lebih dari maupun kurang dari.

Dalam proses pembelajaran, terdapat siswa yang mengalami hambatan dalam memahami materi yang disampaikan guru, sehingga ketika melakukan kegiatan latihan soal siswa tersebut kebingungan dalam memahami soal dan tidak memiliki bayangan langkah penyelesaiannya. Guru sering memberikan soal-soal latihan yang mirip dengan contoh-contoh soal yang diberikan guru atau contoh-contoh soal yang ada pada buku paket, namun ada saja siswa yang masih belum bisa mengerjakan dengan baik.

Kegiatan pembelajaran yang dilaksanakan guru belum memfasilitasi siswa yang mengalami hambatan belajar. Hal ini menyebabkan peran aktif siswa yang mengalami hambatan belajar tersebut semakin tertinggal dibandingkan dengan temantemannya. Dengan kata lain keikutsertaannya secara aktif di dalam pembelajaran masih sangat minim.

Berdasarkan tes assesment pra pembelajaran pada materi nilai mutlak, dimana materi ini telah dipelajari oleh siswa, menunjukkan bahwa terdapat siswa yang mendapatkan nilai jauh di bawah rata-rata kelas. Berdasarkan penuturan siswa, alasannya kesulitan menyelesaikan soal tersebut dikarenakan ia tidak memahami maksud yang disampaikan dalam soal yang diberikan. Siswa belum memiliki bahan untuk bantuan belajar, khususnya LKS dan contoh-contoh soal yang detail dan memudahkan siswa dalam memahami materi pembelajaran.

Analisis pada konsep-konsep yang akan diajarkan pada proses pembelajaran yang bertujuan untuk mengidentifikasi, merinci dan menyunsun secara sistematis konsep-konsep relevan yang akan diajarkan berdasarkan analisis ujung depan. Berdasarkan revisi kurikulum 2013 yang mulai diberlakukan Juli 2016 untuk kelas X semester Gasal maka materi yang aka dibahas adalah persamaan dan pertidaksamaan nilai mutlak linear satu variabel, pertidaksamaan rasional dan irrasional satu variabel, sistem pertidaksamaan linear tiga variabel, sistem pertidaksamaan dua variabel (linear kuadrat dan kuadrat-kuadrat), serta fungsi. Materi yang akan diujicobakan ke kelas
X MIPA 1 SMA N 1 Turi adalah persamaan dan pertidaksamaan nilai mutlak linear satu variabel.

Analisis terhadap tugas-tugas berupa kompetensi yang akan dikembangkan dalam proses pembelajaran. Berdasarkan analisis siswa dan analisis konsep nilai mutlak, maka tugas-tugas yang dilakukan siswa selama proses pemebelajaran adalah sebagai berikut:

1) Menemukan konsep nilai mutlak

a) Menggambar sketsa nilai mutlak dalam garis bilangan

b) Mengetahui definisi dan sifat nilai mutlak

2) Menggambar grafik fungsi nilai mutlak

a) Menentukan titik-titik koordinat cartesius

b) Memasangkan titik-titik koordinat cartesius ke dalam sumbu koordinat cartesius

3) Meyelesaikan persamaan nilai mutlak bentuk linear satu variabel

a) Memahami konsep nilai mutlak

i) Mengetahui definisi matematika dari nilai mutlak

ii) Mengetahui definisi geometri dari nilai mutlak

b) Menentukan penyelesaian nilai mutlak menggunakan langkah-langkah yang mudah dipahami

i) Membagi sebuah persamaan menjadi dua persamaan, yaitu sebuah persamaan positif dan sebuah persamaan negatif

ii) Menyelesaikan persamaan (menentukan hasil penyelesaian persamaan)

iii) Memeriksa hasil penyelesaian

4) Menyelesaikan pertidaksamaan nilai mutlak bentuk linear satu variabel

a) Mengevaluasi bentuk pertidaksamaan

b) Menentukan penyelesaian nilai mutlak menggunakan langkah-langkah yang hampir mirip seperti saat menyelesaikan persamaan nilai mutlak

i) Mengubah pertidaksamaan nilai mutlak menjadi pertidaksamaan biasa

ii) Mencari nilai $x$ yang mungkin dengan mengabaikan tanda pertidaksamaan

iii) Memeriksa kembali hasil pekerjaan

iv) Menuliskan jangkauan himpunan penyelesaian 
Hasil analisis tugas dan analisis konsep menjadi tujuan pencapaian hasil belajar. Adapun perincian dari hasil analisis tujuan pembelajaran tersebut adalah:

1) Siswa dapat menemukan konsep nilai mutlak

a) Siswa dapat menggambar sketsa nilai mutlak dalam garis bilangan

b) Siswa mengetahui definisi dan sifat nilai mutlak

2) Siswa dapat menggambar grafik fungsi nilai mutlak

a) Siswa dapat menentukan titik-titik koordinat cartesius

b) Siswa dapat memasangkan titik-titik koordinat cartesius ke dalam sumbu koordinat cartesius

3) Siswa dapat meyelesaikan persamaan nilai mutlak bentuk linear satu variabel

a) Siswa dapat memahami konsep nilai mutlak

i) Siswa mengetahui definisi matematika dari nilai mutlak

ii) Siswa mengetahui definisi geometri dari nilai mutlak

b) Siswa dapat menentukan penyelesaian nilai mutlak menggunakan langkahlangkah yang mudah dipahami

i) Siswa dapat membagi sebuah persamaan menjadi dua persamaan, yaitu sebuah persamaan positif dan sebuah persamaan negatif

ii) Siswa dapat menyelesaikan persamaan (menentukan hasil penyelesaian persamaan)

iii) Siswa dapat memeriksa hasil penyelesaian

4) Siswa dapat menyelesaikan pertidaksamaan nilai mutlak bentuk linear satu variabel

a) Siswa dapat mengevaluasi bentuk pertidaksamaan

b) Siswa dapat menentukan penyelesaian nilai mutlak menggunakan langkahlangkah yang hampir mirip seperti saat menyelesaikan persamaan nilai mutlak

i) Siswa dapat mengubah pertidaksamaan nilai mutlak menjadi pertidaksamaan biasa

ii) Siswa dapat mencari nilai $x$ yang mungkin dengan mengabaikan tanda pertidaksamaan

iii) Siswa dapat memeriksa kembali hasil pekerjaan iv) Siswa dapat menuliskan jangkauan himpunan penyelesaian

Design

Dilakukan tindak lanjut terhadap temuan-temuan pada tahap analisis dengan mendesain solusi dari permasalahanpermasalahan yang ditemukan. Tahap ini merupakan tahapan pembuatan desain dan pengembangan perangkat pembelajaran matematika yang terdiri dari Rencana Pelaksanaan Pembelajaran (RPP), dan Lembar Kegiatan Siswa (LKS).

RPP yang dikembangkan menggunakan model discovery learning dengan metode ceramah, diskusi, tanya jawab dan penugasan, serta menggunakan pendekatan scientific. Secara garis besar, rencana pelaksanaan pembelajaran tersebut menggambarkan bahwa tujuan pembelajaran mengarah kepada pemahaman konsep siswa. Kegiatan pembelajaran dirancang untuk memfasilitasi siswa untuk memudahkan memahami konsep yang disampaikan baik dalam materi pembelajaran maupun dalam soal.

Penyusunan rencana pelaksanaan pembelajaran mengacu pada Peraturan Menteri Pendidikan Dan Kebudayaan Republik Indonesia Nomor 103 Tahun 2014 yang mencakup: (1) identitas sekolah/madrasah, mata pelajaran, dan kelas/semester; (2) alokasi waktu; (3) KI, KD, indikator pencapaian kompetensi; (4) materi pembelajaran; (5) kegiatan pembelajaran; (6) penilaian; dan (7) media/alat, bahan, dan sumber belajar (Kemendikbud, 2014: 4).

Prototipe pengembangan RPP memuat komponen-komponen antara lain: komponen identitas; kompotensi inti; kompetensi dasar dan indikator pencapaian kompetensi; tujuan; materi pembelajaran; model pembelajaran; kegiatan pembelajaran; penilaian; serta media/alat, bahan dan sumber pembelajaran.

Lembar Kegiatan Siswa (LKS) yang dikembangkan mengakomodir hambatan siswa sehingga dapat meminimalisir kelemahan siswa dalam belajar matematika. Berdasarkan kelemahan-kelemahan siswa yang telah diuraikan pada pembahasan sebelumnya hal-hal yang termuat dalam LKS tersebut antara lain: Petunjuk yang jelas dan detail mengenai isi LKS tersebut, baik petunjuk sebelum mengerjakan, ketika pengerjaan maupun hal- 
hal yang sebaiknya dilakukan ketika telah menyelesaikan mengerjakan seluruh isi LKS.

LKS harus memberikan persoalan matematika yang beraneka ragam dari yang termudah hingga yang tersulit untuk tiap-tiap kompetensi dasar yang ada serta memberikan berbagai bentuk soal dari soal terbuka seperti soal uraian panjang yang memiliki jawaban panjang pula, soal cerita yang dapat berupa soal pilihan ganda maupun soal uraian, soal open ended yang setiap siswa bisa menjawab dengan jawaban yang tidak sama satu sama lain (atau memang terdapat/dibuat aturan tersendiri dalam latihan soal tersebut bahwa jawaban setiap anak tidak bolah sama), maupun soal tertutup seperti pilihan ganda, soal benar salah, mencocokkan soal dengan jawaban yang telah disediakan dan berbagai bentuk soal yang lain.

Sebuah rangkaian LKS minimal memuat satu kompetensi dasar sehingga dalam tiap-tiap soalnya minimal memuat satu indikator ketercapaian kompetensi, sehingga dengan harapan apabila seorang siswa dapat mengerjakan persoalan tersebut dengan baik maka telah tercapai satu indikator dalam kompetensi dasar tersebut. Selain itu LKS harus memberikan contoh menyelesaikan persoalan, langkah-langkah yang terdapat dalam contoh soal tersebut harus disertai penjelasan mengapa bisa begitu, mengapa tidak menggunakan cara lain oleh karena itu siswa harus dibiasakan untuk gemar membaca, membaca apapun termasuk petunjuk mengerjakan soal, karena jika tidak maka siswa langsung terfokus menuju ke soal tanpa membaca contoh soal maupun petunjuk pengerjaan soal.

LKS dirancang berdasarkan KD dan disesuaikan dengan RPP yang dikembangkan. Rancangan awal LKS disusun dengan tujuan untuk memfasilitasi siswa yang mengalami hambatan belajar agar terbantu dalam kegiatan pembelajarannya. Tahapan yang dilakukan dalam pengembangan LKS antara lain: mempersiapkan referensi yang akan digunakan untuk mengembangkan materi sebagai dasar penyusunan LKS. Adapun referensi yang digunakan untuk menyusun LKS meliputi: Fahnani, B.R., Kirana, C., \& Gunarso, D. (tidak mencantumkan tahun penerbitan). Matematika SMA/MA dan SMK/MAK Kelas X Semester 1. Klaten: Viva Pakarindo serta Kemendikbud. (2016). Lampiran 16 Peraturan Menteri Pendidikan dan Kebudayaan RI No.24 tahun 2016, tentang Kompetensi Inti Dan Kompetensi
Dasar Pelajaran Pada Kurikulum 2013, Pada Pendidikan Dasar Dan Pendidikan Menengah dan Purcell, E.J., Varberg, D., \& Rigdon, S.E., (2003). Kalkulus Jilid 1 edisi 9. Jakarta: Erlangga.

Tahapan selanjutnya yaitu menyusun alur materi sehingga diharapkan materi yang disusun dapat dirancang dengan baik. Susunan alur materi dibuat setelah peneliti menyusun analisis materi dan menentukan materi yang terdiri dari materi yang sesuai dengan KD yang telah dijabarkan ke dalam beberapa indikator. Melalui alur materi diharapkan materi yang di ajarkan sesuai dengan kebutuhan siswa dan tidak ada materi yang terlewatkan. Setelah disusun alur materi, langkah selanjutnya adalah perincian materi yang kemudian dikembangkan menjadi materi LKS. Konten dalam LKS disusun berdasarkan KD yang telah ditentukan. Penulisan LKS menggunakan program Microsoft Word 2013.

Lembar kegiatan siswa yang dikembangkan memuat komponen-komponen: identitas LKS dan alokasi waktu; tujuan; petunjuk pengerjaan; kegiatan siswa; kesimpulan; serta instrumen assesment pra pembelajaran.

\section{Development}

Fase development/pengembangan dalam penelitian ini berupa: Pertimbangan ahli terhadap perangkat pembelajaran dan instrumen, dalam hal ini dilakukan oleh dua dosen ahli di bidang pendidikan matematika dan pendidikan luar biasa. Proses ini bertujuan untuk memperoleh saran, pendapat, dan evaluasi dari ahli terkait kelayakan produk yang dikembangkan.

Pelaksanaan uji coba perangkat pembelajaran yang diikuti dengan evaluasi. Tahapan ini juga mencakup penilaian kelayakan dari produk pengembangan yang ditinjau dari aspek kepraktisan dan keefektifan. Penilaian kepraktisan dilakukan oleh guru matematika kelas X MIPA 1 dan siswa kelas X MIPA 1 SMA N 1 Turi. Sedangkan penilaian terhadap perangkat pembelajaran ditinjau dari aspek keefektifan melalui proses uji coba yang kemudian dianalisis untuk menentukan keefektifan produk yang dikembangkan. Dari hasil analisis dilakukan revisi untuk mendapatkan perangkat akhir yang sesuai dengan kebutuhan pembelajaran. 
Kevalidan produk pengembangan yang dibuktikan melalui validitas isi menunjukkan bahwa perangkat pembelajaran yang dikembangkan didasarkan atas teori-teori yang digunakan sebagai pedoman dalam merumuskan dan menyusun perangkat pembelajaran. Dengan terpenuhinya aspek kevalidan tersebut, maka produk pengembangan berupa perangkat pembelajaran matematika kelas $X$ semester ganjil bagi siswa yang mengalami hambatan belajar dalam pembelajaran matematika dinyatakan layak untuk digunakan dengan revisi sesuai saran dan masukan dari validator.

Kepraktisan perangkat pembelajaran digunakan untuk mengetahui kemudahan penggunaan perangkat dalam pembelajaran, bagi guru maupun siswa, yang penilaiannya didasarkan pada penilaian guru dan penilaian siswa dalam menggunakan perangkat pembelajaran, serta hasil observasi keterlaksanaan pembelajaran.

Hasil penilaian guru terhadap perangkat pembelajaran yang dikembangkan secara kualitatif berada pada kriteria sangat baik untuk RPP dan baik untuk LKS. Hal ini menunjukkan bahwa perangkat pembelajaran yang dikembangkan dapat diterapkan dengan mudah oleh guru dalam pembelajaran. Hasil penilaian siswa terhadap perangkat pembelajaran secara kualitatif berada pada kriteria baik. Hal ini menunjukkan bahwa siswa juga dapat menggunakan dan memanfaatkan perangkat pembelajaran yang dikembangkan secara mudah. Berdasarkan hasil penilaian guru, penilaian siswa, dan hasil observasi keterlaksanaan pembelajaran tersebut, maka dapat disimpulkan bahwa perangkat pembelajaran matematika kelas $\mathrm{X}$ semester ganjil bagi siswa yang mengalami hambatan belajar dalam pembelajaran matematika memenuhi kriteria praktis.

Produk pengembangan berupa perangkat pembelajaran matematika kelas $\mathrm{X}$ semester ganjil bagi siswa yang mengalami hambatan belajar dalam pembelajaran matematika memenuhi kriteria efektif. Keefektifan perangkat pembelajaran matematika dilihat dari persentase ketuntasan belajar siswa yang mencapai $70,58 \%$.

Tercapainya ketuntasan belajar siswa, menjadi bukti bahwa siswa yang mengalami hambatan belajar dapat dibantu dalam proses pembelajaran agar seluruh siswa dapat mencapai tujuan pembelajaran bersama-sama atau dapat mencapai kriteria ketuntasan sesuai yang ditentukan. Hal ini tentu saja membutuhkan kerja keras dan kerja sama antara guru, siswa pandai, siswa lain serta siswa yang mengalami hambatan belajar. Selain itu pemberian detail pembahsan permasalahan melalui LKS menjadikan siswa lebih terbantu untuk menggali ide yang dapat digunakan untuk memecahkan masalah tersebut. Tentu saja peran siswa pandai di dalam kelas untuk menjelaskan maksud yang disampaikan dalam LKS juga penting, karena tidak semua siswa merasa bahwa dia nyaman bertanya langsung kepada guru. Beberapa siswa cenderung lebih nyaman dan berani untuk bertanya kepada kawannya yang dianggap lebih pandai di sebuah kelas.

Faktor lain yang menyebabkan ketuntasan belajar siswa adalah adanya kegiatan dalam pembelajaran yang berupa pengerjaan soal yang rutin dan bertingkat. Pada awalnya guru memberikan soal yang ringanringan, apabila siswa lancar dalam mengerjakan maka tingkat kesulitan soal dianikkan begitu seterusnya sampai tujuan pembelajaran yang diinginkan tercapai. Dengan demikian terjadinya peningkatan pemahaman belajar siswa menjadi salah satu faktor penentu tercapainya tujuan pembelajaran.

\section{SIMPULAN DAN SARAN SIMPULAN}

Perangkat pembelajaran persamaan dan pertidaksamaan nilai mutlak linear satu variabel bagi siswa yang mengalami hambatan belajar matematika memiliki karakteristik: Pada tiap akhir materi guru melakukan evaluasi, setelah evaluasi tersebut siswa yang belum menguasai materi pelajaran diberikan pengajaran remedial; menggunakan soal-soal yang memiliki tingkat kesulitan yang berjenjang; menggunakan instrumen evaluasi berupa tes akhir yang disesuaikan dengan kemampuan siswa.

Produk pengembangan memenuhi kriteria valid. Dengan klasifikasi secara kualitatif adalah baik untuk dosen ahli 1 serta cukup untuk dosen ahli 2; praktis, terlihat dari skor hasil penilaian guru terhadap kepraktisan perangkat dengan klasifikasi secara kualitatif sangat baik; skor hasil penilaian siswa terhadap kepraktisan perangkat dengan klasifikasi secara 
kualitatif baik; dan rerata persentase keterlaksanaan pembelajaran pada kegiatan guru dan siswa di atas 90\%; dan efektif, dibuktikan dari persentase ketuntasan belajar siswa yang mencapai 70,58 \%, melebihi kriteria yang ditetapkan yaitu $70 \%$.

\section{SARAN}

Produk pengembangan pembelajaran persamaan dan pertidaksamaan nilai mutlak linear satu variabel bagi siswa yang mengalami hambatan belajar matematika dapat dijadikan referensi atau pedoman bagi guru untuk mengembangkan perangkat pembelajaran yang sesuai dengan tuntutan Kurikulum 2013, baik pada materi atau pun pelajaran lain.

Guru dapat mengembangkan kembali perangkat yang dikembangkan tersebut disesuaikan dengan kebutuhan siswa dalam pembelajaran dengan melengkapi maupun mengubah beberapa detail yang dirasa kurang sesuai untuk siswa yang bersangkutan. Dalam memanfaatkan produk pengembangan ini, guru disarankan untuk selalu memberikan motivasi terutama kepada siswa yang mengalami hambatan belajar sehingga diperoleh respon yang baik dari siswa dalam kegiatan pembelajaran. Selain itu guru hendaknya memilih masalah yang aktual berkaitan dengan materi.

\section{DAFTAR PUSTAKA}

Abdurrahman, M. (2003). Pendidikan bagi anak berkesulitan belajar. Jakarta: Rineka Cipta.

Arjmandnia, A. A., \& Kakabaraee, K. (2011). The investigation of parents' attitude toward inclusive education for slow learners [Versi Elektronik]. International Journal on New Trends in Education and Their Implications, Volume: 2.

Benassi, V. A., Overson, C. E., \& Hakala, C. M. [Ed.]. (2014). Applying science of learning in education: Infusing psychological science into the curriculum. Diambil pada tanggal 11 Maret 2017 dari the Society for the Teaching of Psychology website: http://teachpsych.org/ebooks/asle2014/i ndex.php.
Bransford, J. D., Brown, A. L., \& Cocking, R. R. [Ed.] (1999). How people learn, brain, mind, experience, and school, expanded edition. Washington DC: National Academy Press.

Brantingler, E. A. (Ed.). (2006). Who benefits from special education? (fixing) remediating other people's children. London: Lawrence Erlbaum Associates, Publishers.

Brown, R. (1999). Philosophy of mathematics, a contemporary introduction to the world of proofs and pictures, second edition. New York: Routledge.

Butcher, C., Davies, C. \& Highton, M. (2006). Designing learning from module outline to effective teaching. New York: Routledge.

Fink, L. D. (2003). Creating significant learning experiences, an integrated approach to designing college courses. San Fransisco: Jossey-Bass A Wiley Imprint

Hasratuddin. (2008). Permasalahan pembelajaran matematika sekolah dan alternatif pemecahannya [Versi Elektronik]. Jurnal Pythagoras, 4 (1), 67-73.

Hott, B. L., Isabell, L., \& Montani, T. O. (2014). Strategies and interventions to support students with mathematics disabilities [Versi Elektronik]. Journal of Council for Learning Disabilities.

Kemendikbud. (2016). Lampiran 16 Peraturan Menteri Pendidikan Dan Kebudayaan Republik Indonesia Nomor 24 Tahun 2016 tentang Kompetensi Inti dan Kompetensi Dasar Matematika SMA/MA/SMK/MAK.

Marsigit., Rizkianto, I., \& Murdiyani, N. M. (2014). Filsafat matematika. Yogyakarta: UNY Press.

Mundia, L. (2012). The assessment of math learning difficulties in a primary grade- 4 child with high support needs: mixed methods approach [Versi Elektronik]. International Electronic Journal of Elementary Education. 
NCERT (National Council of Educational Research and Training). (2006). Position paper national focus group on teaching of mathematics. New Delhi: National Council of Educational Research and Training.

Rumasoreng, M. I. \& Sugiman (2014). Analisis kesulitan matematika siswa SMA/MA dalam menyelesaikan soal setara UN di Kabupaten Maluku Tengah [Versi Elektronik]. Jurnal Riset Pendidikan Matematika, 1 (1), 22-34.

Sadidah, Ai \& Wijaya, Aryadi (2006). Pengembangan perangkat pembelajaran matematika SMP kelas VIII semester genap untuk siswa berkebutuhan khusus berorientasi pada minat dan prestasi belajar. Tesis, tidak diterbitkan. Universitas Negeri Yogyakarta.
Seifert, K., \& Sutton, R. (2009). Educational psychology, second edition. Zurich: The Saylor Foundation.

Tambychik, T. \& Meerah, T. S. M. (2010). Students' difficulties in mathematics problem-solving: what do they say? [Versi Elektronik]. Procedia Social and Behavioral Sciences 8 (2010) 142-151.

Thiagarajan, S. Smmel, D. S., \& Smmel, M. I. (1974). Instructional development for teacher of exceptional children. Blomington: Indiana University.

Wigner, E. (1960). The unreasonable effectivenss of mathematics in the natural sciences [Versi Elektronik]. Communications in Pure and Applied Mathematics, Vol. 13, No. I. 